\title{
Analysis of Ceramic Sherds from the Mid-18th Century Gilbert Site on Lake Fork Creek, Rains County, Texas
}

Timothy K. Perttula

Heritage Research Center, Stephen F. Austin State University

Follow this and additional works at: https://scholarworks.sfasu.edu/ita

Part of the American Material Culture Commons, Archaeological Anthropology Commons, Environmental Studies Commons, Other American Studies Commons, Other Arts and Humanities Commons, Other History of Art, Architecture, and Archaeology Commons, and the United States History Commons

Tell us how this article helped you.

This Article is brought to you for free and open access by the Center for Regional Heritage Research at SFA ScholarWorks. It has been accepted for inclusion in Index of Texas Archaeology: Open Access Gray Literature from the Lone Star State by an authorized editor of SFA ScholarWorks. For more information, please contact cdsscholarworks@sfasu.edu. 


\section{Analysis of Ceramic Sherds from the Mid-18th Century Gilbert Site on Lake Fork Creek, Rains County, Texas}

\section{Creative Commons License}

\section{(c) (1) (8)}

This work is licensed under a Creative Commons Attribution-NonCommercial 4.0 International License 


\title{
Analysis of Ceramic Sherds from the Mid-18th Century Gilbert Site on Lake Fork Creek, Rains County, Texas
}

\author{
Timothy K. Perttula
}

\section{INTRODUCTION}

The Gilbert site (41RA13) is an important mid-18th century American Indian site on an alluvial terrace along Lake Fork Creek, adjacent to the upper part of Lake Fork Reservoir in Rains County, Texas (Figure 1). The site was first investigated in 1962 by the Dallas Archeological Society (Harris and Harris 1962), and based on the findings from that work, the Texas Archeological Society (TAS) had a field school at the site in June and July 1962 (Jelks 1962:6).

There are several notable features of the Gilbert site. First, it contains 21 midden mounds about 6-9 m in diameter and ca. $1 \mathrm{~m}$ in height spread out over ca. 50 aces of the alluvial terrace landform (see Figure 1). The middens do not represent habitation features, as the "only occupational features discovered besides the middens were two pits that were evidently used for storing grain or other products. No house floors, post-mold patterns, burials, hearths, or other such structural remains were found" (Jelks 1967:6). Further investigation by Blaine $(1992: 178,182)$ identified other midden features (discussed further below, and the source of the ceramic sherds discussed in this article) and a well-preserved bell-shaped storage pit in Feature 20. The newly-discovered midden features were not mounded or had a clay cap, and neither contained any evidence of structural remains or features. Structural features are considered more likely to be found in inter-midden areas than in the middens themselves.

A second notable feature of the Gilbert site is the abundance of mid-18th century European trade goods in the archeological deposits, much of it likely obtained from French traders. These goods include metal tools (knives, axes, wedges, hatchets, hoes, scrapers, awls, chisels, scissors, arrow points, and a Spanish sword hilt), gun parts, ornaments (especially glass trade beads), brass kettles, horse trappings, flat and bottle glass, and chipped glass pieces (Jelks 1967:18-111; Blaine 1988, 1992).

Third, there was a substantial aboriginal ceramic sherd assemblage from the Gilbert site (Story et al. 1967). The analysis of the sherds suggested that they are from vessels "too stylistically and technologically diverse to represent only one locally-produced ceramic complex" (Story et al. 1967:186; italics in the original). Furthermore, "the majority, and perhaps even all, of the decorated ceramics [at the site] are derived ultimately from the Caddoan [sic], particularly Fulton Aspect [Late Caddo period], tradition. Many close parallels exist in the modes and styles of decoration, paste characteristics, and vessel forms" (Story et al. 1967:187).

And lastly, the various results of the investigations suggested that the site was a village occupied by southern Wichita groups, possibly the Tawakoni, Kichai, or Yscani Indians (Jelks 1967:244). This conclusion is far from uniformly accepted (see Gregory 1973; Perttula 1992, 2007), a point I will return to in the final section of this article. In the remainder of this article, I discuss the analysis of a small collection of previously unstudied ceramic sherds from two midden features (F-B3 and F-B4) excavated by Jay and Jerrylee Blaine from the Gilbert site. The focus of the analysis is to characterize the principal stylistic and technological characteristics of the ceramic sherd assemblages from these two middens, compare this assemblage in those aspects with the larger assemblage from numerous middens studied by Story et al. (1967), and then offer my own interpretation of the cultural affiliations of the Gilbert site occupants based on the ceramic sherd assemblage data. 


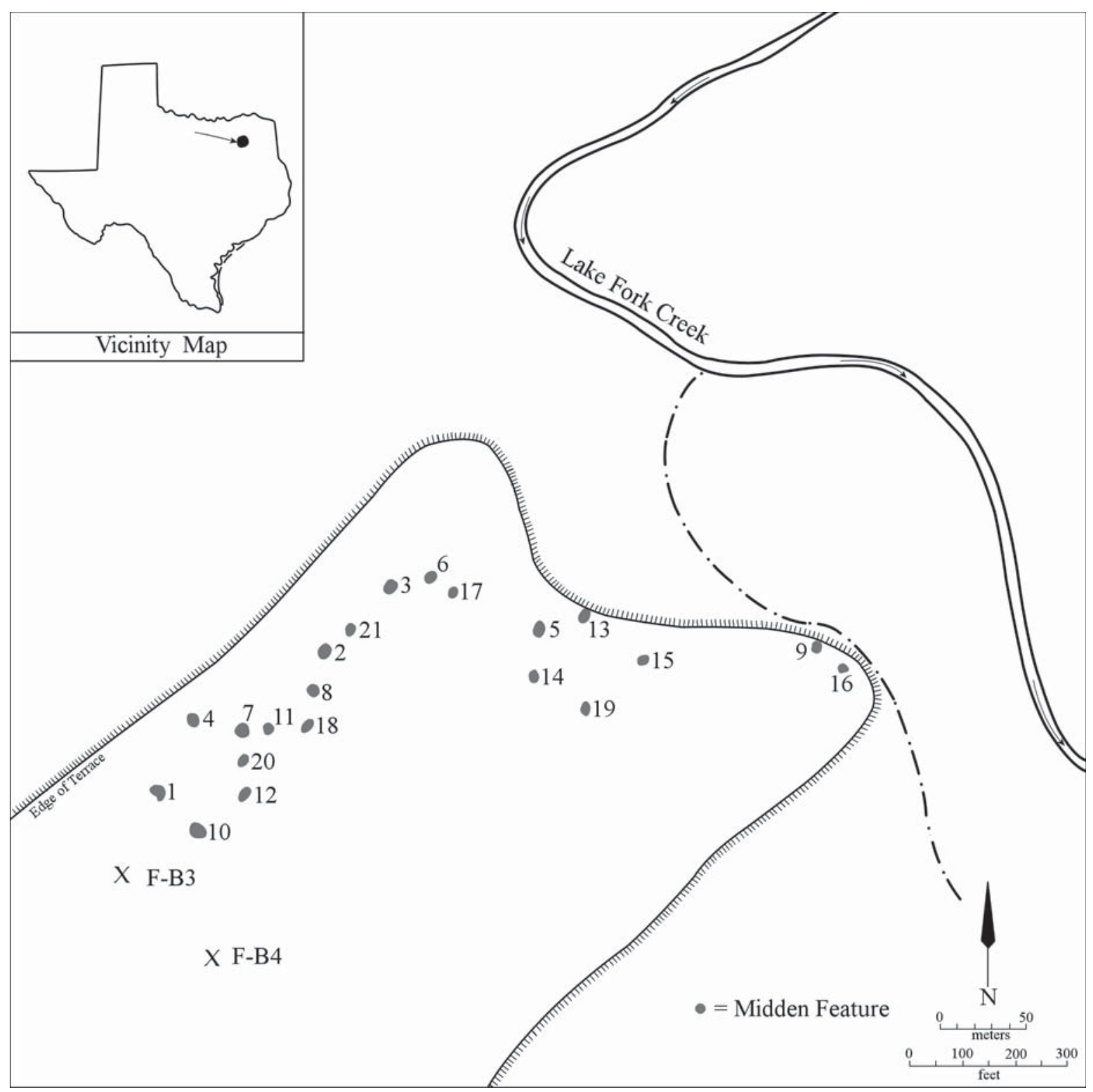

Figure 1. Map of the Gilbert site, showing the location of midden features 1-21 and features F-B3 and F-B4.

\section{SITE BACKGROUND AND JAY BLAINE INVESTIGATIONS}

In the years following the TAS field school, Jay and Jerrylee Blaine identified and investigated two midden features at the Gilbert site, labeled Feature F-B3 and Feature F-B4, in the southern and western parts of the alluvial terrace landform (see Figure 1). According to Jay Blaine, "these features were isolated individual middens and both are outside the previously known main site feature pattern. Feature F-B3's surface was even with the surrounding ground. Feature F-B4 was slightly elevated above the surrounding ground's surface" (Jay Blaine, August 18, 2010 personal communication). Blaine also noted that both features "lacked a clay topping but had the usual assortment of deer and box turtle remnants, glass beads, metals, etc. F-B3 contained the two unused metal hoes [see Blaine 1992:Figure 3] as well as some scarce (wine?) bottle evidence" (Jay Blaine, August 18, 2010 personal communication). Neither midden provided any direct evidence of structural remains, such as post holes, floors, pits, or concentrations of daub. 


\section{CERAMIC SHERD ASSEMBLAGE}

As already mentioned, the ceramic sherds analyzed for this article are from the Blaine's excavations in Middens F-B3 and F-B4 (see Figure 1). This includes 53 sherds from F-B3 and 69 sherds from F-B4. There are a few pieces of burned clay $(n=2)$ and sherdlets $(n=7$; sherds less than $1 \mathrm{~cm}$ in length and width) in the collections, but these are not further considered herein.

The analysis of the ceramic sherds from the Gilbert site is based on differences in temper and paste, type of sherd (i.e., rim, body, or base), rim and lip form (cf. Brown 1996:Figure 2-12), decoration (if present, including the identification of motifs and elements), surface treatment (smoothing, burnishing, or polishing; see Rice 1987), and firing conditions (cf. Teltser 1993). Temper is the deliberate and indeterminate materials found in the paste (Rice 1987:411), including a variety of tempers (grog or crushed sherds, burned mussel shell, burned bone, etc.). Sherd cross-sections were inspected macroscopically and with a 10X hand lens to determine the character of the paste and its inclusions. Determining the firing conditions was based on the identification of the firing core in the sherd cross-sections and the identification of oxidation patterns as defined in Teltser (1993:535-536 and Figure 2a-h) and Perttula (2005:Figure 5-30i1). Finally, wall thickness was recorded in millimeters $(\mathrm{mm})$, using a vernier caliper, along the mid-section of the sherd (see Appendix 1).

\section{F-B3 Sherds}

The 53 sherds from midden F-B3 include seven rim sherds, 45 body sherds, and one base sherd. They are from vessels made with six different temper-paste combinations, five of which have a clayey to silty paste: shell-tempered ( $\mathrm{n}=18$, including four rims, $37.5 \%$ of the sherds from the midden that were analyzed for temper and paste); bone-tempered ( $\mathrm{n}=13$, including two rims, $27.1 \%)$; grog-tempered $(\mathrm{n}=7,14.6 \%)$; bone-hematite-tempered $(n=7$, including one rim, $14.6 \%)$; fine sandy paste $(n=2,4.2 \%)$, and groghematite-tempered $(n=1,2.1 \%)$. Differences in temper-paste and firing conditions (see below) suggest that the 53 sherds may be from as many as 19 separate vessels or vessel fragments that were discarded in the F-B3 midden.

Fourteen sherds, including two rims, are from the decorated portions of vessels. One is a small engraved sherd with a row of small engraved triangles (Figure 2b), probably from what Story et al. (1967:127) have identified as a Natchitoches Engraved variant bowl or carinated bowl with a fine sandy paste. The other 13 decorated sherds are from utility ware jars, including sherds with brushed $(n=7)$, incised $(n=4)$, punctated $(n=1)$, and grooved $(n=1)$ elements.

The brushed sherds from F-B3 are from bone-tempered $(n=4)$ and bone-hematite-tempered $(n=3)$ jars. Six have parallel brushing marks on them, probably representing the vertical brushing of jar body sections, and a seventh has opposed brushing marks. All four of the incised sherds are from shell-tempered jars. One Emory Punctated-Incised body sherd has parallel to curvilinear incised lines on it (cf. Story et al. 1967:Figure 57h), two others have closely-spaced curvilinear or straight incised lines, and the fourth incised body sherd has widely-spaced parallel incised lines as well as a single opposed diagonal incised line (Figure 3f).

The punctated sherd is an Emory Punctated-Incised jar rim (everted rim with rounded lip) with at least two rows of punctations beginning just below the vessel lip (see Figure 3e). It is a shell-tempered vessel. Another shell-tempered rim (direct rim and a rounded lip) has a broad horizontal grooved line below the lip. Similar grooved pottery vessels of the Lindsey Grooved type have been identified in 18th century Hasinai Caddo ceramic assemblages in the Neches-Angelina river basin in East Texas (Marceaux 2011), but they are tempered with grog or bone, never shell.

The plain rims from F-B3 are shell-tempered $(n=2)$, bone-tempered $(n=2)$, and bone-hematite-tempered $(n=1)$. The shell-tempered rims are from everted rim jars with rounded lips. The bone-hematitetempered rim is from a jar with a direct rim and a rounded lip. The two bone-tempered rims are from two 


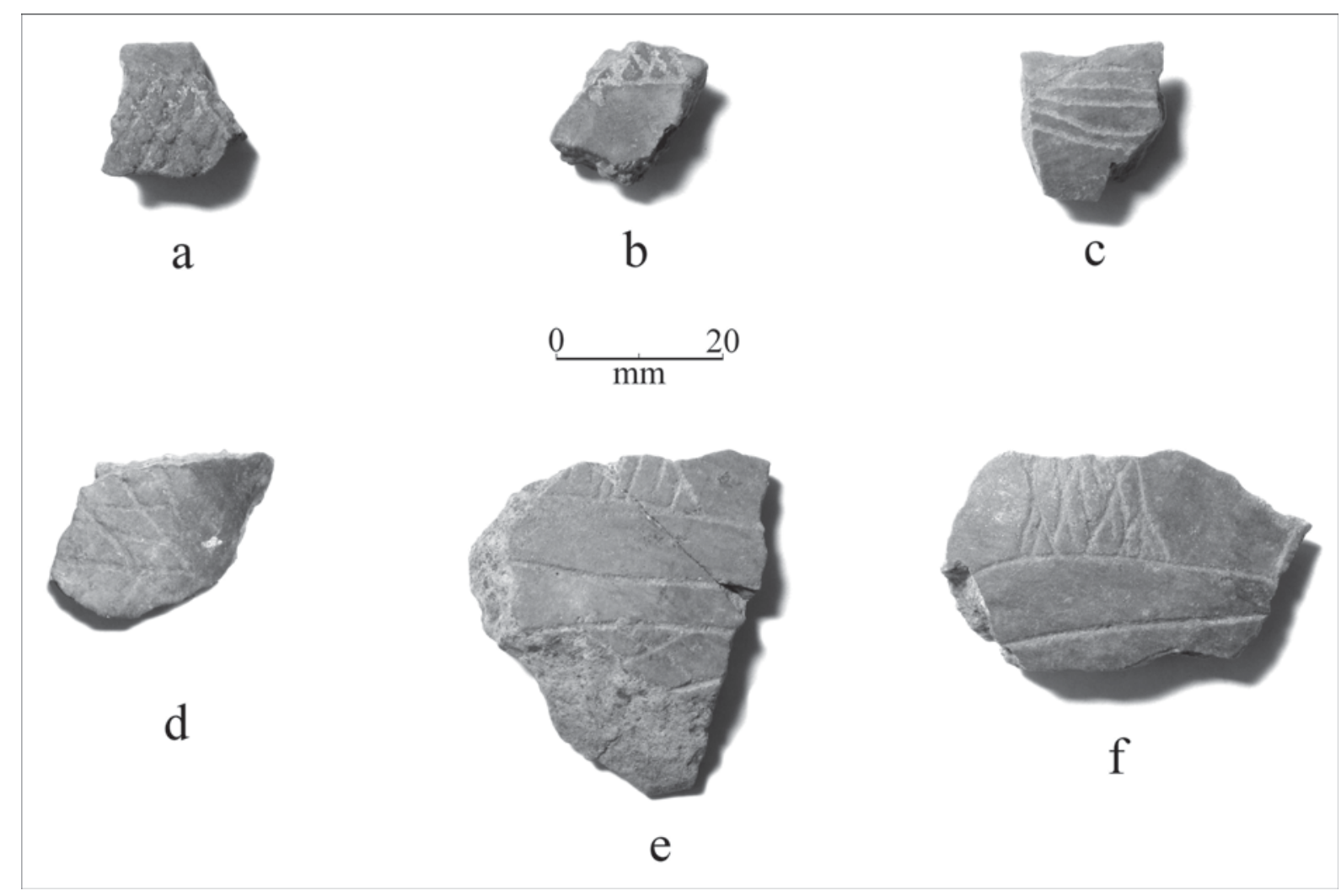

Figure 2. Engraved sherds from F-B3 and F-B4 middens: a, Womack Engraved; b, cf. Natchitoches Engraved, variant; c, Natchitoches Engraved variant; d, cross-hatched engraved zone; e, Natchitoches Engraved variant; f, Natchitoches Engraved variant. Provenience: a, F-B4, Lot 9; b, F-B3, Lot 25; c, F-B4, Lot 57; d, F-B4, Lot 57; e, F-B4, Lot 80; f, F-B4, Lot 73 .

different vessels. The first of these is from a jar with organic residue preserved on its exterior surface. The rim is direct, with a flat and exterior folded lip. The second bone-tempered rim is a short inverted and interior thickened rim, perhaps from a Simms Engraved or Simms Plain carinated bowl or Womack Ware (Story et al. 1967:148-149), that has a rounded lip.

The different temper-paste sherd groupings from the F-B3 midden are from vessels that were fired in a variety of ways (Table 1). Shell-tempered vessels were overwhelmingly fired in a low oxygen or reducing environment, a firing strategy designed to improve the success in firing vessels with shell temper (see Feathers and Peacock 2008). Bone-tempered, grog-tempered, and bone-hematite-tempered sherds are from vessels primarily fired in a reducing environment, but cooled in the open air, leaving a thin lens of oxidized or lighter surface color along one or both vessel surfaces. Sherds from both incompletely oxidized and reduced-fired vessels are represented in the fine sandy paste sherds, while the grog-hematitetempered sherds are from both vessels fired in an oxidizing environment as well as vessels that were sooted, smudged, or refired (Table 1).

In terms of surface treatment of the F-B3 sherds, both the bone-tempered and shell-tempered sherds are from vessels with interior smoothing (56-71\% of the sherds from these groups with evidence of surface treatment); presumably this smoothing was done to decrease the permeability of these utility ware vessels used for cooking and food storage. Approximately $33 \%$ of the bone-tempered sherds have interior and/or exterior burnished surfaces, and are likely from bowls and carinated bowls. Burnished vessel surfaces are especially common on fine sandy paste (50\%) and grog-tempered $(85.7 \%)$ sherds, indicating that these temper-paste groupings are also primarily from burnished fine ware vessels that were discarded in the F-B3 midden. 


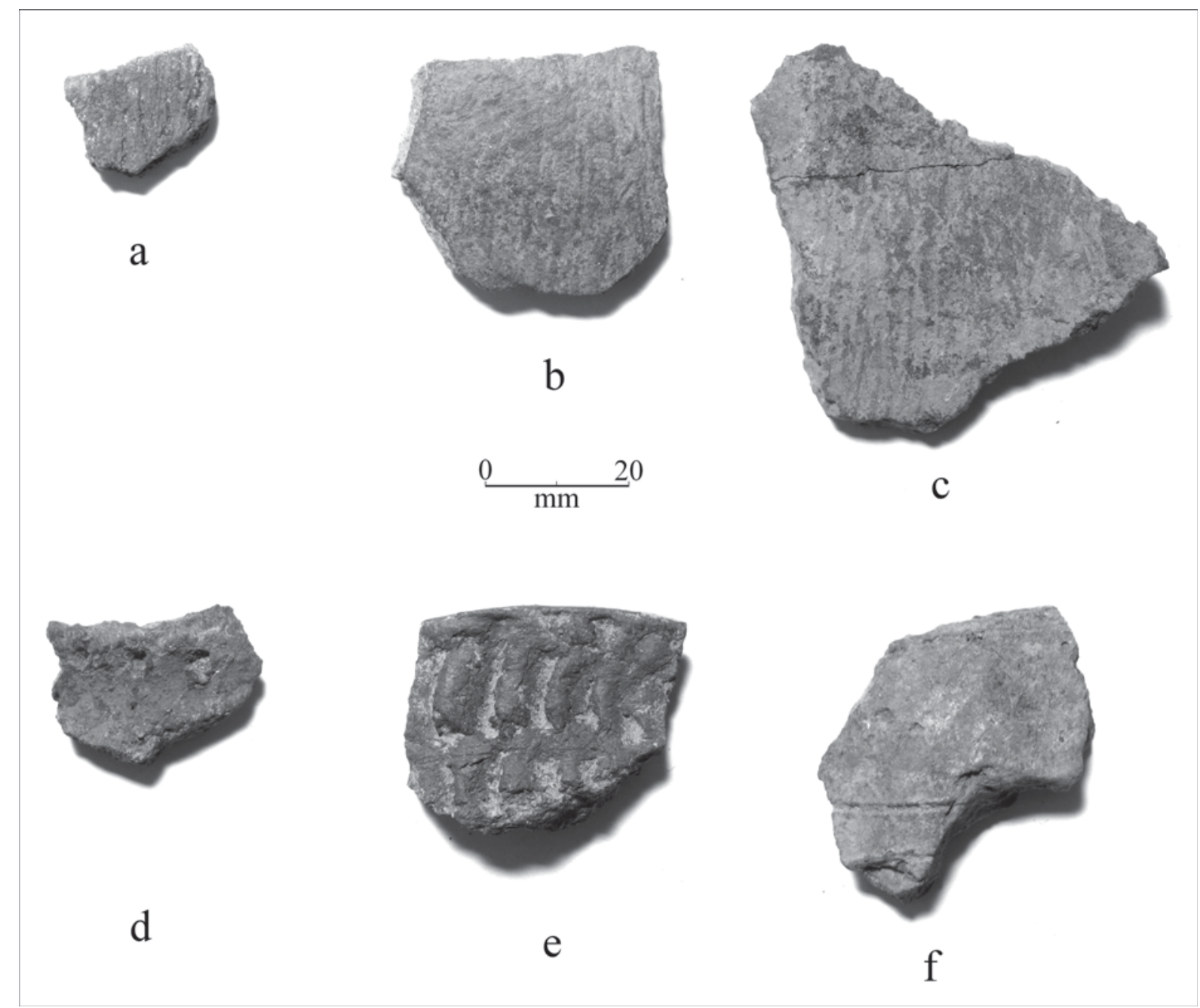

Figure 3. Utility ware sherds from the F-B3 and F-B4 middens: a, parallel brushed; b, horizontal and overlapping brushed; c, parallel brushed; d, tool punctated row at rim-body juncture; e, Emory Punctated, f, parallel and diagonal incised lines. Provenience: a, F-B4, Lot 74; b, F-B4, Lot 55; c, F-B4, Lot 39; d, F-B4, Lot 26; e, F-B3, Lot 28; f, F-B3, Lot 24.

In general, the sherds from the F-B3 midden are from moderately thin-walled vessels with rim thickness ranges of 5.4-8.9 mm and body sherd thickness ranges of 4.6-8.4 $\mathrm{mm}$. The one base sherd is 8.4 $\mathrm{mm}$ thick. The bone-tempered sherds are from vessels of two different thickness ranges: 4.5-5.6 mm and 6.5-7.0 mm, presumably reflecting size differences, while the shell-tempered sherds (both rim and body sherds) have a continuous thickness range of 6.1-7.8 $\mathrm{mm}$, and the grog-tempered body sherds have a continuous thickness range of 6.3-7.4 mm. The one fine ware body sherd (fine sandy paste) is $6.7 \mathrm{~mm}$ thick, while the decorated utility ware sherds range from $6.9-8.3 \mathrm{~mm}$ (rim) to 5.4-7.8 mm (body) in thickness.

\section{F-B4 Sherds}

The F-B4 midden has 69 sherds, five rim sherds, 63 body sherds, and one base sherd. They are made from nine different temper-paste combinations, six of which have a clayey to silty paste: bone-tempered $(\mathrm{n}=27$, including one rim, representing $45 \%$ of the 60 sherds analyzed in detail from this midden); fine sandy paste-hematite-tempered $(n=10,16.7 \%)$; fine sandy paste $(n=9,15 \%)$; shell-tempered $(n=5,8.3 \%$, including one rim); grog-tempered $(\mathrm{n}=5,8.3 \%$, including two rims); bone-hematite-tempered $(\mathrm{n}=1$, $1.7 \%)$; grog-bone-tempered $(\mathrm{n}=1,1.7 \%)$; bone-shell-tempered $(\mathrm{n}=1,1.7 \%)$; and fine sandy paste-shelltempered, $\mathrm{n}=1,1.7 \%$ ). Differences in temper-paste and firing conditions (see below) suggest that the 69 
Table 1. Firing conditions for the F-B3 sherds.

\begin{tabular}{lllllll}
\hline Firing conditions & bone & shell & fSP & grog & bone-hematite & grog-hematite \\
\hline Oxidizing & - & $5.6^{*}$ & - & - & - & 33.3 \\
Incompletely oxidized & 7.7 & - & 50.0 & 14.3 & - & - \\
Reducing & 23.1 & 94.4 & - & - & 28.6 & - \\
$\begin{array}{l}\text { Reduced, but cooled } \\
\text { in open air }\end{array}$ & 61.5 & - & 50.0 & 71.4 & 71.4 & - \\
$\begin{array}{l}\text { Sooted, smudged, } \\
\text { or refired }\end{array}$ & 7.7 & - & - & 14.3 & - & 66.7 \\
\hline \begin{tabular}{l} 
Totals \\
\hline$p$
\end{tabular} & 13 & 18 & 2 & 7 & 7 & 3 \\
\hline
\end{tabular}

*percentage; fSP=fine sandy paste

sherds may be from as many as 20 separate vessels or vessel fragments that were discarded in the F-B4 midden.

Forty-one sherds, including two rims, are from the decorated portions of vessels. About $41 \%(\mathrm{n}=17)$ are from engraved $(n=16)$ and red-slipped $(n=1)$ fine ware vessels. The other 24 decorated sherds are from utility ware jars, including sherds with brushed $(n=22)$, incised $(n=1)$, and punctated $(n=1)$ elements.

The engraved sherds from fine ware vessels include one rim sherd and 16 body sherds. The rim sherd (direct rim and a rounded lip) is from a grog-tempered Womack Engraved vessel that has a cross-hatched engraved zone that begins below the lip (see Figure 2a). Three other body sherds from F-B4, two with a fine sandy paste (one of which has pieces of crushed hematite temper), have cross-hatched engraved Womack Engraved designs (see Figure 2d). Six engraved body sherds resemble the Natchitoches Engraved variant group defined by Story et al. (1967:127-129 and Figure 54c-bb); they are from sandy paste and sandy paste-hematite-tempered burnished vessels. Each of the sherds have hachured triangular areas (see Figure 2c, e) and/or brackets (see Figure 2f) embedded in or pendant from areas of straight and diagonal engraved lines. One of these sherds has a brown-colored slip on interior and exterior vessel surfaces.

One small body sherd has two closely-spaced horizontal engraved lines, suggestive of Simms Engraved, but the lines lack tick marks. Story et al's (1967:133 and Figure 56a-b) engraved Sherd Group 1 have horizontal engraved lines. Other engraved sherds have closely-spaced parallel lines $(n=1)$, straight and curvilinear lines ( $n=1$, fine sandy paste), parallel and opposed lines $(n=1$, fine sandy paste and hematite-tempered), one bottle sherd with curvilinear lines, and one body sherd with opposed engraved lines ( $\mathrm{n}=1$, bone- and shell-tempered).

The one red-slipped sherd is a rim (direct rim and a rounded lip) from a grog-tempered bowl. The bowl has a hematite-rich clay slip on both vessel surfaces. Red-slipped vessels are a distinctive feature of Middle (ca. A.D. 1200-1450) and Late (ca. A.D. 1450-1680) Caddo ceramic assemblages in East Texas, particularly in the upper basins of the Red, Sulphur, Big Cypress, and Sabine River stream basins. Caddo groups that remained in one or all of these areas-except in the Red River, where after ca. A.D. 1300, all ceramics were tempered with shell-in the mid-18th century may be the source of this fine ware at the Gilbert site.

More than $95 \%$ of the brushed sherds have parallel brushing marks on them (see Figure $3 \mathrm{a}, \mathrm{c}$ ). The other has horizontal and overlapping brushing marks (see Figure 3b). Most of the brushed sherds are from bone-tempered vessels $(n=16)$, with smaller numbers of sherds with grog temper $(n=2)$ or a non-tempered fine sandy paste $(n=1)$. 
The incised and punctated sherds are from shell-tempered and bone-tempered vessels. The incised sherd, probably from an Emory Punctated-Incised jar, has only a single straight incised line on it, while the punctated bone-tempered vessel sherd from a second Emory Punctated-Incised jar has a row of tool punctations at the rim-body juncture (see Figure 3d). Story et al. (1967:137) describe the temper and paste of Emory Punctated-Incised vessels as having either sandy paste, sandy paste and shell-tempered, sandy paste and grog-tempered, or sandy paste and bone-tempered in "varying quantities."

The plain rims from F-B4 are shell-tempered $(n=1)$ and bone-tempered $(n=1)$; the temper and paste was not analyzed on a small third rim. The shell-tempered rim is from a bowl or carinated bowl with an inverted rim and a rounded lip, perhaps from a Womack Plain vessel or Womack Ware (Story et al. 1967:146, 148-149 and Figures 60 and 61), that has a rounded lip. The bone-tempered rim is from a jar with an everted rim and a rounded and exterior folded lip. The third plain rim also has a rounded and exterior folded lip, and may also be from a jar.

The different temper-paste sherd groupings from the F-B4 midden are from vessels that were fired in a variety of ways (Table 2). Bone-tempered, fine sandy paste, grog-tempered, shell-tempered, fine sandy paste-hematite-tempered, grog-bone-tempered, bone-shell-tempered, and fine sandy paste-shell-tempered sherds are from vessels primarily if not exclusively fired in a reducing environment. Those with bone temper and a fine sandy paste tended to also be cooled in the open air, leaving a thin lens of oxidized or lighter surface color along one or both vessel surfaces. Temper-paste groups that were primarily fired and cooled in a reducing environment-leaving the vessel sherds with a black core and a very dark gray to black color on both vessel surfaces - include the grog-tempered, shell-tempered, and bone-shell-tempered groups (Table 2). Sherds from both incompletely oxidized and oxidized-fired vessels are represented in the fine sandy paste sherds, the bone-hematite-tempered sherds, and the shell-tempered group. One shelltempered sherd is from a vessel that was sooted, smudged, or refired (Table 2).

Table 2. Firing conditions for the F-B4 sherds.

\begin{tabular}{|c|c|c|c|c|c|c|c|c|c|}
\hline Firing conditions & $\mathrm{b}$ & fSP & $\mathrm{g}$ & b-h & sh & fSP-h & g-b & b-sh & fSP-sh \\
\hline Oxidizing & - & - & - & $100.0 *$ & - & - & - & - & - \\
\hline $\begin{array}{l}\text { Incompletely } \\
\text { oxidized }\end{array}$ & - & 14.3 & - & - & 20.0 & - & - & - & - \\
\hline Reducing & 42.9 & 28.6 & 80.0 & - & 40.0 & - & - & 100.0 & - \\
\hline $\begin{array}{l}\text { Reduced, but } \\
\text { cooled in open air }\end{array}$ & 57.1 & 57.1 & 20.0 & - & 20.0 & 100.0 & 100.0 & - & 100.0 \\
\hline $\begin{array}{l}\text { Sooted, smudged, } \\
\text { or refired }\end{array}$ & - & - & - & - & 20.0 & - & - & - & - \\
\hline Totals & 28 & 7 & 5 & 1 & 5 & 9 & 1 & 1 & 1 \\
\hline
\end{tabular}

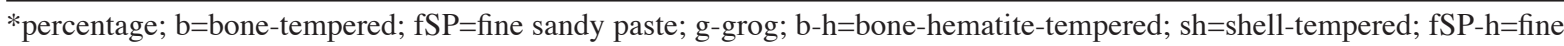
sandy paste and hematite-tempered; $g$-b=grog-bone-tempered; $b$-sh; bone and shell-tempered; fSP-sh=fine sandy paste and shell-tempered

Both the bone-tempered, fine sandy paste, and grog-tempered sherds in the F-B4 midden are from vessels with interior smoothing (40-61\% of the sherds from these groups with evidence of surface treatment); Utility wares tended to be smoothed on the interior vessel surface, primarily to lower the permeability and increase the heating effectiveness of particular vessels (see Rice 1996:148), namely the utility ware vessels used for cooking. Between 7.1-42.9\% of the fine sandy paste and bone-tempered sherds are 
also smoothed on their exterior surfaces, and these are likely from bowls and carinated bowls. Interior and/or exterior burnished surfaces on sherds from bowls and carinated bowls are also common in the F-B4 ceramic assemblage, except in the bone-tempered sherds, where burnished sherds are conspicuous in their absence in the F-B4 midden, but are relatively abundant in the F-B3 midden assemblage. Burnished vessel surfaces are especially common on fine sandy paste $(57.1 \%)$, grog-tempered $(80.0 \%)$, shelltempered (60\%), fine sandy paste-hematite-tempered (67\%), and bone-shell-tempered (100\%) sherds. These temper-paste groupings are also primarily from burnished fine ware vessels that were discarded in the F-B4 midden.

Comparable to the sherds from the F-B3 midden, the F-B4 sherds are from moderately thin-walled vessels with rim thickness ranges of 4.2-7.0 mm and body sherd thickness ranges of 3.6-8.0 mm. The one base sherd is $9.2 \mathrm{~mm}$ thick. The bone-tempered sherds are from vessels of two different thickness ranges: 4.7-6.6 $\mathrm{mm}$ and 6.9-7.2 $\mathrm{mm}$, presumably reflecting vessel size differences, and there are also two thickness/size ranges apparent in the fine sandy paste sherds (5.3-6.6 $\mathrm{mm}$ and 7.3-8.0 $\mathrm{mm}$ ); the grog-tempered sherds (5.1-5.6 $\mathrm{mm}$ and 6.1-6.6 $\mathrm{mm}$ ); the shell-tempered sherds $(5.6 \mathrm{~mm}$ and 6.5-7.0 $\mathrm{mm})$; and the fine sandy paste-hematite-tempered sherds (5.1-5.6 mm and 6.7-7.6 mm). The mean thickness of the F-B4 fine ware rim sherds $(\mathrm{n}=2)$ is $5.3 \pm 1.2 \mathrm{~mm}$, and the fine ware body sherd mean thickness is $6.39 \pm 0.73 \mathrm{~mm}$. The decorated utility ware body sherds have a mean thickness of $5.92 \pm 0.61 \mathrm{~mm}$.

\section{COMPARISONS TO EARLIER GILBERT SITE SHERD ANALYSES}

The ceramic sherds from the F-B3 and F-B4 middens are from the same range of broken vessels of various kinds as has been documented by Story et al. (1967). As enumerated in Table 3, the sherds from other middens at the Gilbert site are dominated by those from Womack Engraved, incised and punctated Emory Punctated-Incised vessels, brushed and brushed-combed jars, Natchitoches Engraved and Natchitoches Engraved variant bowls and carinated bowls, and Simms Engraved vessels. In the F-B3 and F-B4 middens, brushed sherds are abundant (especially in F-B4), there are Emory Punctated-Incised jar sherds, as well as sherds from Womack Engraved and Natchitoches Engraved vessels; there are no sherds from Simms Engraved vessels, although one rim sherd from F-B3 may be from a Simms Plain vessel (or Womack Plain). The ceramics from the FB-3 and F-B4 middens are clearly from the same component as the 21 other midden features distributed across the Gilbert site.

Looking in more detail at the distribution of the different kinds of decorated and plain ceramic types and groups, Womack Engraved vessel sherds, bone-tempered sherds, and shell-tempered sherds are the most widely distributed at the Gilbert site, being found with some frequency in virtually every one of the investigated middens, including F-B3 and F-B4 (Figure 4a, d-e and Table 4). These comprise the key set of ceramic fine wares and plain wares in this mid-18th century ceramic assemblage, along with Womack Plain, Womack Ware, incised sherds, and Natchitoches Engraved.

The principal cluster (i.e., highest percentages in the various investigated middens, ranging from 12.7-51.4\%) of Womack Engraved sherds at the Gilbert site is in the southwestern part of the site (see Figure 4a). Natchitoches Engraved and Natchitoches Engraved variant sherds occur in two small clusters in the southwestern (and includes F-B3 and F-B4 middens) and northwestern parts of the site (see Figure $4 \mathrm{~b}$ ), in frequencies ranging between $6.1-9.1 \%$ of the sherds in each investigated midden.

Brushed pottery has a wide distribution across the Gilbert site, occurring in middens from the southwestern and northwestern parts of the site as well as in a central area cluster (see Figure 4c). Brushed sherds are abundant in both F-B3 and F-B4 middens (13.2-31.9\%), as they are in middens $6(9.1 \%), 12$ $(25.7 \%)$, and $15(12.9 \%)$.

Bone-tempered sherds occur throughout the site, but the highest proportions (27.1-87.9\%) of bonetempered sherds are found in midden features (including F-B3 and F-B4) in the southwestern part of the 
Table 3. Decorated sherds from features (see Story et al. 1967:Tables 7 and 8).

\begin{tabular}{llllllllllll}
\hline Fea. No. & WE & NE & ME & SE & P & I & $\begin{array}{l}\text { B-Cl } \\
\text { C }\end{array}$ & $\begin{array}{l}\text { A/ } \\
\text { A-I }\end{array}$ & EP & B & B-P \\
\hline 1 & & & & & & & & & \\
2 & 48 & 2 & 9 & 29 & 5 & 9 & - & 1 & 2 & 4 & 13 \\
3 & 31 & - & 5 & 28 & - & 7 & - & - & - & 2 & - \\
4 & 48 & 40 & 40 & - & - & 20 & 37 & - & - & 32 & - \\
5 & 23 & 2 & 3 & - & 3 & 5 & - & 1 & 9 & 9 & 6 \\
6 & 19 & - & 9 & 1 & 7 & 27 & - & 2 & - & 1 & - \\
7 & 4 & 17 & 17 & - & - & 18 & - & - & 1 & 17 & - \\
8 & 9 & 10 & 1 & 1 & 2 & 1 & 9 & - & - & 3 & - \\
10 & - & - & - & - & - & 1 & 1 & - & - & 2 & - \\
11 & - & 1 & 2 & - & - & - & - & - & - & - & - \\
12 & 6 & - & 1 & - & - & 1 & - & - & - & - & - \\
15 & 18 & - & 2 & - & 1 & - & - & - & - & 9 & - \\
16 & 1 & - & 1 & - & - & - & 1 & - & - & 4 & - \\
17 & 1 & - & 1 & - & - & 2 & - & - & - & - & - \\
$18 *$ & 6 & - & - & - & - & 1 & - & - & - & - & - \\
19 & 1 & - & - & - & - & 1 & - & - & - & 1 & - \\
20 & - & - & - & - & - & 3 & - & - & - & - & - \\
\hline Totals & 21 & - & - & - & - & - & - & - & - & 1 & - \\
\hline$W E$ & 216 & 72 & 91 & 59 & 18 & 96 & 47 & 4 & 12 & 85 & 19 \\
\hline
\end{tabular}

$\mathrm{WE}=$ Womack Engraved an variants; $\mathrm{NE}=$ Natchitoches Engraved and variants; $\mathrm{ME}=$ miscellaneous engraved; $\mathrm{SE}=\mathrm{Simms}$ Engraved; $\mathrm{P}=$ punctated; $\mathrm{I}=$ incised; $\mathrm{B}-\mathrm{C}=$ brushed-combed; $\mathrm{C}=$ combed; $\mathrm{A}=$ appliqued; $\mathrm{A}-\mathrm{I}=$ appliqued-incised; $\mathrm{EP}=\mathrm{Emory}$ Punctated; $\mathrm{B}=$ brushed; $\mathrm{B}-\mathrm{P}=$ brushed-punctated

*does not include four pinched sherds

site (see Figure 4d). Midden 18 has the highest proportion (87.9\%) of bone-tempered sherds. Shell-tempered sherds are primarily clustered in the same middens where bone-tempered sherds predominate (see Figure 4e), except that middens in the northwestern (Midden 3) and north central (Midden 5) areas, as well as Midden 16 in the northeast part of the site, also have considerable proportions of shell-tempered ceramics. The proportion of shell-tempered pottery in these middens ranges from 19.7 to $80 \%$. Middens where grog-tempered sherds are common cluster in the southwestern (including F-B3 and F-B4) and northwestern (Midden 6) parts of the Gilbert site (see Figure 4f).

\section{CONCLUSIONS}

The analysis of the ceramic sherds from the F-B3 and F-B4 middens at the southern end of the Gilbert site has disclosed that they contain the same range of Caddo decorated fine wares and utility wares, namely Womack Engraved, Natchitoches Engraved variant, Emory Punctated-Incised, and brushed jars, as has been previously documented by Story et al. (1967) from the other investigated middens at the site (see also Table 3). Furthermore, the temper and paste groups in these assemblages, including shell- 

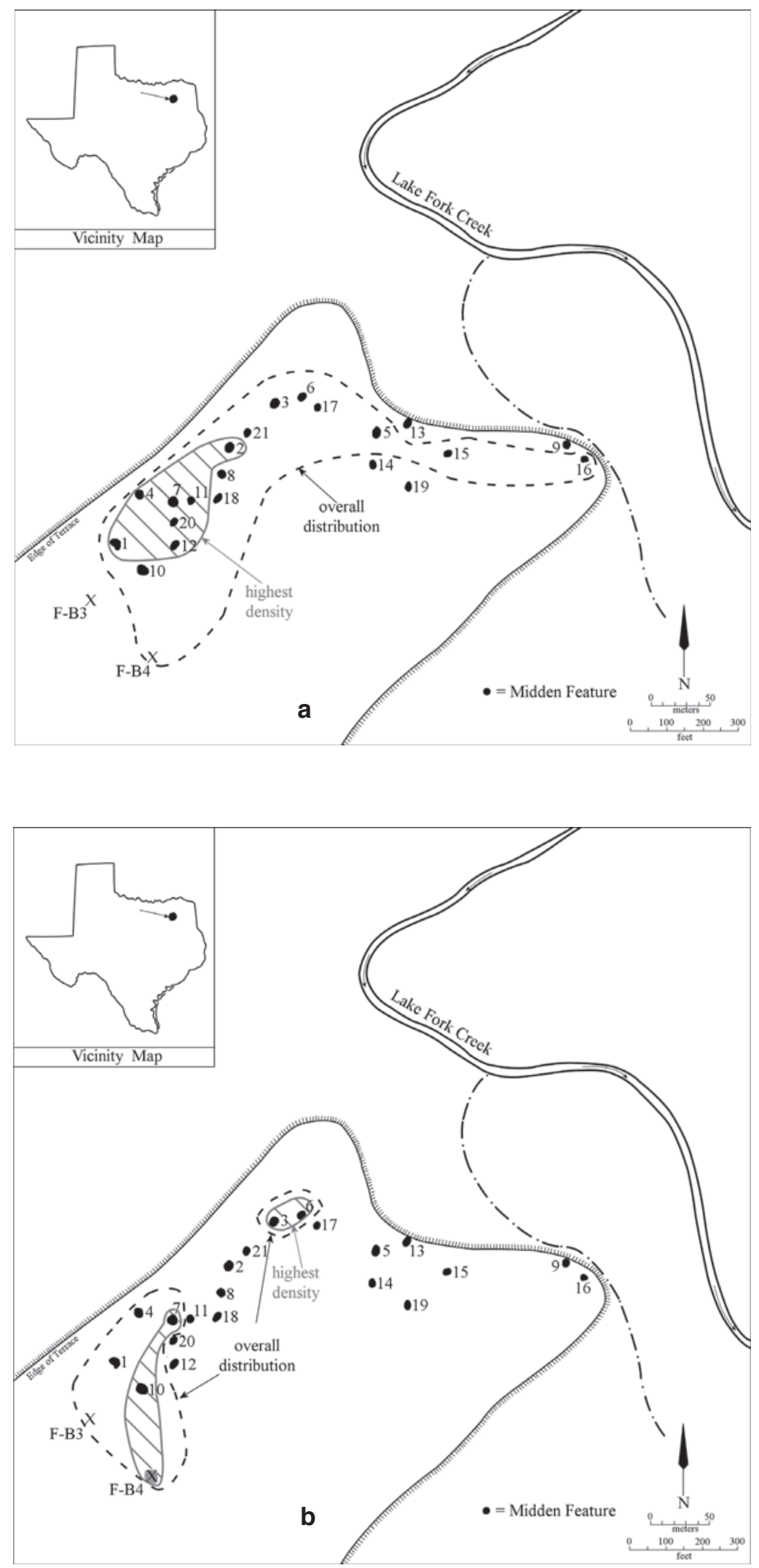

Figure 4. Distribution and highest percentages of selected ceramic types and groups at the Gilbert site: a, Womack Engraved; b, Natchitoches Engraved and variants;. 

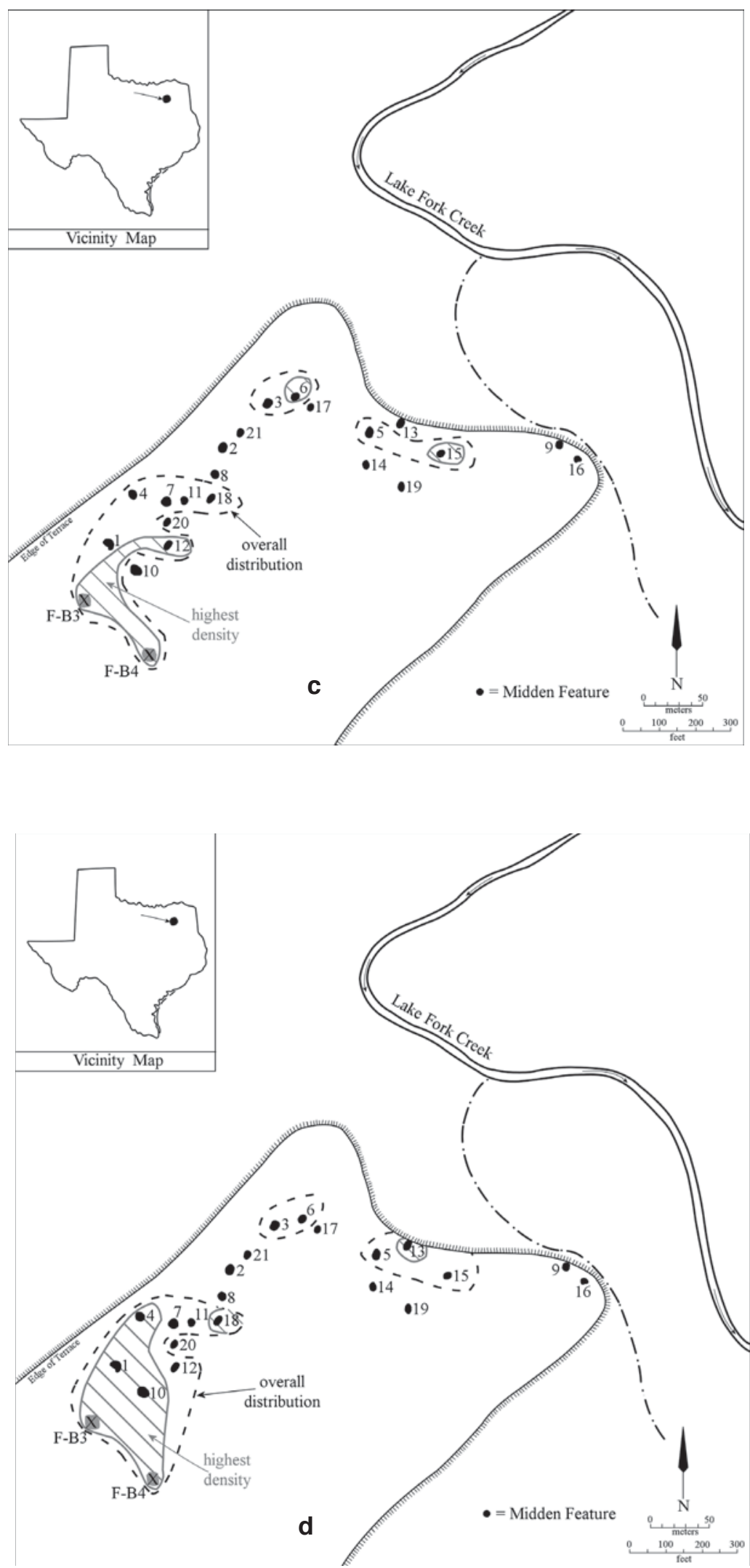

Figure 4. Distribution and highest percentages of selected ceramic types and groups at the Gilbert site: c, brushed pottery; d, bone-tempered sherds. 

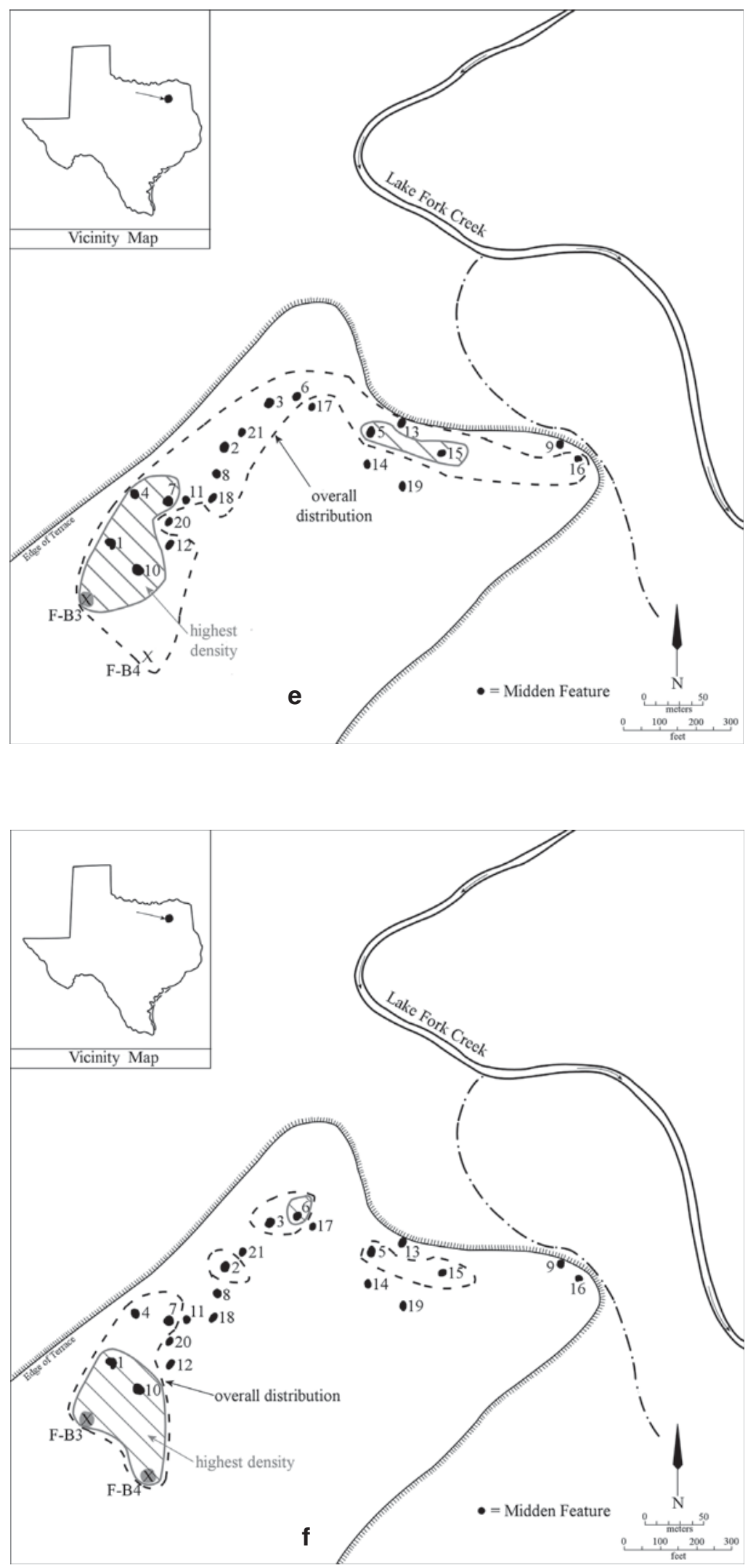

Figure 4. Distribution and highest percentages of selected ceramic types and groups at the Gilbert site: e, shell-tempered sherds; f, grog-tempered sherds. 
Table 4. Plain sherds from features (see Story et al. 1967:Tables 7 and 8).

\begin{tabular}{lllllllll}
\hline Fea. No. & WP & WW & shell & shell-bone & bone & grog & grog-shell & SP \\
\hline 1 & 1 & - & 83 & - & 97 & 42 & - & 27 \\
2 & - & - & 11 & - & - & 1 & - & 3 \\
3 & 91 & 120 & 148 & - & 108 & 6 & 1 & 48 \\
4 & - & 3 & 46 & 1 & 56 & 1 & 1 & 7 \\
5 & 1 & 37 & 77 & - & 24 & 6 & - & 5 \\
6 & 1 & 2 & 35 & - & 16 & 18 & 14 & 24 \\
7 & 16 & - & 44 & 2 & 14 & 1 & - & 1 \\
10 & - & - & 2 & - & 3 & 4 & - & 1 \\
11 & - & 2 & - & - & 1 & - & - & 2 \\
12 & - & - & 4 & - & 1 & - & - & - \\
13 & - & - & 3 & - & 2 & - & - & - \\
15 & 1 & - & 12 & 2 & 5 & 1 & - & 2 \\
16 & - & - & 16 & - & 16 & - & - & - \\
18 & - & - & 1 & - & 58 & - & - & - \\
20 & - & - & - & - & - & - & - & 1 \\
\hline Totals & 111 & 164 & 482 & 5 & 401 & 80 & 16 & 121 \\
\hline
\end{tabular}

$\mathrm{WP}=$ Womack Plain; WW=Womack ware; $\mathrm{SP}=$ sandy paste

tempered, bone-tempered, grog-tempered, and fine sandy paste as the principal temper-paste groups, are the same as the temper-paste groups from the other middens (see Table 4). The F-B3 midden ceramics are notable for the high proportions of shell-, bone-, and grog-tempered sherds, and the abundance of brushed jar sherds, while F-B4 has high proportions of bone-tempered and fine sandy paste sherds, along with a very high proportion of brushed jar sherds; Natchitoches Engraved variant sherds are also well represented in this midden.

The predominance of Caddo fine ware, utility ware, and plain ware vessel sherds in the various midden features at the Gilbert site strongly suggest that the site was occupied by Caddo peoples that made, used, and broke ceramic vessels during the course of the mid-18th century occupation. Instrumental neutron activation analysis of three sherds from the Gilbert site (Perttula and Ferguson 2010:Figure 3) indicate that they came from vessels made with local sub-region 5 clays in the upper Sabine River basin. This finding leads to the presumption that the sherds are from vessels that were made from local upper Sabine River basin clays. Does this presumption of local manufacture support the conclusion that the vessel sherds found at the Gilbert site were made by Caddo peoples rather than non-Caddo Wichita-Tawakoni or Kichai groups? There are several lines of ceramic evidence that lend credence to the idea that the Gilbert site ceramics are the product of a Caddo occupation, but a contemporaneous occupation by two or more Caddo groups.

First, since the 1960s Womack Engraved has been viewed as a material culture trait diagnostic of the Norteno focus, and has been specifically linked with 18th century Norteno groups living on the southern Plains. These groups are all considered to be non-southern Caddo groups but Wichita-Tawakoni or Kichai in cultural affiliation (Duffield and Jelks 1961:80; Harris et al. 1965:360; Jelks 1967:244). The relatively frequent occurrence of inverted rim engraved vessels from a number of late 17th century Caddo sites in 
the Sabine, Sulphur, and Little Cypress drainage basins in East Texas (see Perttula 2007:137-141) provide evidence of protohistoric settlement in these areas. They also provide stylistic evidence for the development of early 18th century Womack Engraved vessels out of a late 17th century Titus phase stylistic tradition that included distinctive red-slipped Taylor Engraved and Ripley Engraved inverted rim vessels. Perttula (2007:141-142) has stated the key stylistic and formal relationships between these Caddo ceramic types as including the following:

(a) development of inverted rim carinated bowls;

(b) earlier use of red-slipping on this vessel form; red-slipping is a common decorative element in upper Sabine and upper Big Cypress Titus phase ceramic vessel assemblages;

(c) later use of shell-tempering in this vessel form;

(d) ticked engraved lines, either on scrolls or semi-circles; and

(e) hooked arm scrolls, including the meandering scroll.

Later changes and the full expression of the stylistic character of Womack Engraved included adding cross-hatched border areas or scroll dividers (the earlier inverted rim forms have hatched triangular scroll dividers) and the development of large cross-hatched engraved triangles. These occur either pendant from the vessel rim or pendant from the central engraved line running through the middle of the rim scroll.

These intimate stylistic relationships between Taylor Engraved and Womack Engraved inverted rim vessels dating from ca. A.D. 1670-1730 arising out of a Titus phase ceramic tradition should dispel the notion that Womack Engraved is a Wichita-Tawakoni or Norteno ceramic type. The occurrence of Womack Engraved vessels and their ancestral stylistic forms (i.e., Taylor Engraved inverted rim engraved carinated bowls, Womack Engraved, var. Gum Creek (Perttula and Nelson 2007:Figure 2f), and some red-slipped Ripley Engraved vessels) in burials on late Titus phase sites that lack trade goods indicate that certain Caddo groups still lived in the Sulphur, Sabine, and Little Cypress Creek basins after much of the region had been abandoned around ca. A.D. 1670. These Caddo groups developed this distinctive vessel form and its constellation of stylistic elements and motifs, which reached their full stylistic maturation by the early 18th century at the Womack site on the Red River and by the middle to late 18th century at the Gilbert and Pearson sites in the upper Sabine River basin.

Second, Womack Engraved vessels have been recovered from Fort Coffee phase sites in the Arkansas River basin of eastern Oklahoma (Rogers 2006:Table 2). Baugh (2009:Figure 1) considers Fort Coffee phase sites to represent a protohistoric Wichita group. Rogers (2006:24) indicates that the Womack Engraved in these sites are Caddo trade wares from the Red River basin to the south. Since the Fort Coffee phase sites appear to have been occupied until only ca. A.D. 1660, it is probable that the Womack Engraved vessels found there-if they are indeed stylistically the same as Womack Engraved vessels found on East Texas Caddo sites - must date at the very end of the Fort Coffee phase settlement of this locale. In any case, there does not appear to be any association between this protohistoric Wichita group and the manufacture of Womack Engraved. Instead, Womack Engraved was already being manufactured by that time among several Caddo groups in the upper Sabine River and Sulphur River basins.

Finally, it is worth considering again the suggestion made by Story et al. (1967:186) that the ceramics from the Gilbert site are "too stylistically and technologically diverse to represent only one locallyproduced ceramic complex." When we consider the co-associations between certain kinds of fine wares, utility wares, and plain wares and the use of specific temper-paste groups at the site - from contemporaneous midden feature contexts - this is a sound conclusion. Looking at the kinds of ceramics that were made by Caddo groups in the years and decades preceding the occupation of the Gilbert site, it is possible to venture suggestions about the provenance of the different ceramic wares. The shell-tempered vessel 
sherds at the site, with the exception perhaps of the Natchitoches Engraved sherds that probably have a Northwest Louisiana provenance (Gregory and Avery 2007:Table 1), as well as the shell-tempered Emory Punctated-Incised vessel sherds, must have originated from a Red River Caddo group, probably one living on the middle Red River (Perttula et al.2011:Figure 2), as this is the only part of East Texas where Caddo groups made and used shell-tempered ceramics in any quantity before the early 18th century. Likewise, the bone-tempered and brushed pottery sherds must have originated among Caddo groups in the Neches-Angelina, Sabine, and/or Big Cypress river basins in East Texas who had been making such utility ware jars since the 14th century A.D. I have already linked the manufacture and use of Womack Engraved to protohistoric Caddo sites and contexts in the upper Sabine and Sulphur river basins, where much of the ceramics were made using grog-temper, an ubiquitous part of Caddo ceramic manufacturing traditions across the region. The decorated and plain vessels with a fine sandy paste at the Gilbert site may be a local and mid-18th century ceramic innovation, as non-tempered sandy paste vessels are rare in prehistoric and protohistoric contexts in East Texas Caddo ceramic assemblages.

In sum, the sherds from decorated and plain vessels at the Gilbert site are considered to have been made by different Caddo groups that lived together at the site in the mid-18th century. The Wichita, Tawakoni, or Kichai have no demonstrated ethnic or archaeological affiliations with the distinctive ceramic wares found at the site.

The Caddo groups that lived at the site in the mid-18th century were originally from the middle Red River and parts of the upper Sabine, Sulphur, and Big Cypress stream basins in east Texas. They brought with them their own ceramic traditions, traditions in the making, decorating, and use of fine wares, utility wares, and plain ware vessels that had been developed over several centuries in prehistoric and protohistoric times. These traditions were maintained during the Gilbert site occupation, being found together in spatial clusters in most, if not all, of the midden features that have been investigated there. The co-association of these ceramic traditions, as well as the manufacture of sandy paste decorated and plain wares that may represent the development of a third distinctive and local ceramic tradition, suggest that the Caddo groups co-existed at the site, but had not yet ethnically coalesced as one distinctive and new Caddo group.

\section{ACKNOWLEDGMENTS}

I wish to thank Jay Blaine for the opportunity to analyze the sherds from his Gilbert site collections, and for providing me with information about the F-B3 and F-B4 middens. Lance Trask drafted the Figure 1 and 4 site maps and took the Figure 2 and 3 photographs.

\section{REFERENCES CITED}

Baugh, T. G.

2009 Protohistoric Kirikir ' $i$-s Societies on the Central and Southern Plains. Oklahoma Anthropological Society Bulletin 57:15-59.

Blaine, J. C.

1988 Trade hatchets from the Gilbert Site. The Record, Fiftieth Anniversary Edition 42(3):111-117. Dallas Archeological Society, Dallas, Texas.

1992 A Summary and Discussion of Additional Findings at the Gilbert Site, an Eighteenth-Century Norteno Occupation in Rains County, Texas. Bulletin of the Texas Archeological Society 63:175-196.

Brown, J. A.

1996 The Spiro Ceremonial Center: The Archaeology of Arkansas Valley Caddoan Culture in Eastern Oklahoma. 2 Vols. Memoirs No. 29. Museum of Anthropology, University of Michigan, Ann Arbor. 
Duffield, L. and E. B. Jelks

1961 The Pearson Site: A Historic Indian Site in Iron Bridge Reservoir, Rains County, Texas. Archaeology Series No. 4. Department of Anthropology, The University of Texas at Austin.

Feathers, J. K. and E. Peacock

2008 Origins and Spread of Shell-Tempered Ceramics in the Eastern Woodlands: Conceptual and Methodological Frameworks for Analysis. Southeastern Archaeology 27(2):286-293.

Gregory, H. F.

1973 Eighteenth-Century Caddoan Archaeology: A Study in Models and Interpretation. Ph.D. dissertation, Southern Methodist University, Dallas.

Gregory, H. F. and G. Avery

2007 American Indian Pottery from Historic Period Sites in North Louisiana. Journal of Northeast Texas Archaeology 26:33-76.

Harris, R. K. and I. M. Harris

1962 Another Marker on the Trail of the Norteno: A Preliminary Report on the Gilbert Site. The Record 17(1):2-9. Dallas Archeological Society, Dallas, Texas.

Harris, R. K., I. M. Harris, J. C. Blaine, and J. Blaine

1965 A Preliminary Archeological and Documentary Study of the Womack Site, Lamar County, Texas. Bulletin of the Texas Archeological Society 36:287-363.

Jelks, E. B. (editor)

1967 The Gilbert Site: A Norteno Focus Site in Northeast Texas. Bulletin of the Texas Archeological Society 37:1-248.

Marceaux, P. S.

2011 The Archaeology and Ethnohistory of the Hasinai Caddo: Material Culture and the Course of European Contact. Ph.D. dissertation, Department of Anthropology, The University of Texas at Austin.

Perttula, T. K.

1992 "The Caddo Nation": Archaeological \& Ethnohistoric Perspectives. University of Texas Press, Austin.

2007 Inverted Rim Engraved Vessels in Protohistoric and Early Historic Caddo Sites in Parts of Northeast Texas. Journal of Northeast Texas Archaeology 26:136-144.

Perttula, T. K. (editor)

2005 Archeological Investigations at the Pilgrim's Pride Site (41CP304), a Titus Phase Community in the Big Cypress Creek Basin, Camp County, Texas. 2 Vols. Report of Investigations No. 30. Archeological \& Environmental Consultants, LLC, Austin.

Perttula, T. K. and J. R. Ferguson

2010 The Chemical Variation in Prehistoric and Early Historic Caddo Ceramics in Eastern Texas. In Studies on the Instrumental Neutron Activation Analysis of Woodland Period and Caddo Tradition Ceramics from Eastern Texas, compiled by T. K. Perttula, pp. 3-1 to 3-62. Special Publication No. 17. Friends of Northeast Texas Archaeology.

Perttula, T. K. and B. Nelson

2007 The Gum Creek Cluster: Protohistoric Caddo Sites in the Little Cypress Creek Basin, ca. A.D. 1670-1720. Journal of Northeast Texas Archaeology 26:128-135. 
Perttula, T. K., M. B. Trubitt, and J. S. Girard

2011 The Use of Shell-Tempered Pottery in the Caddo Area of the Southeastern U.S. Southeastern Archaeology, in press.

Rice, P. M.

1987 Pottery Analysis: A Sourcebook. University of Chicago Press, Chicago.

1996 Recent Ceramic Analysis: 1. Function, Style, and Origins. Journal of Archaeological Research 4(2):133-163.

Rogers, J. D.

2006 Chronology and the Demise of Chiefdoms: Eastern Oklahoma in the Sixteenth and Seventeenth Centuries. Southeastern Archaeology 25(1):20-28.

Story, D. A., B. Barber, E. Cobb, H. Cobb, R. Coleman, K. Gilmore, R. K. Harris, and N. Hoffrichter 1967 Pottery Vessels. In The Gilbert Site: A Norteno Focus Site in Northeast Texas, edited by E. B. Jelks. Bulletin of the Texas Archeological Society 37:112-187.

Teltser, P. A.

1993 An Analytic Strategy for Studying Assemblage-Scale Ceramic Variation: A Case Study from Southeast Missouri. American Antiquity 58(3):530-543. 
APPENDIX 1, DETAILED ANALYSIS OF SHERDS FROM F-B3 AND F-B4

\begin{tabular}{|c|c|c|c|c|c|c|}
\hline Lot No. & $\begin{array}{l}\text { Sherd } \\
\text { Type }\end{array}$ & $\begin{array}{l}\text { Temper/ } \\
\text { Paste }\end{array}$ & $\mathrm{FC}$ & ST & $\begin{array}{l}\text { Th } \\
(\mathrm{mm})\end{array}$ & Comments \\
\hline \multicolumn{7}{|l|}{ F-B3 } \\
\hline 8 & body & fine bone & $\mathrm{D}$ & I SM & 5.4 & parallel brushed \\
\hline 9 & body & fine bone & $\mathrm{L}$ & $\mathrm{I} / \mathrm{E} B$ & 6.8 & plain \\
\hline 21 & rim & fine bone & B & - & 5.4 & $\begin{array}{l}\text { plain; direct rim and } \\
\text { flat, ext. folded lip }\end{array}$ \\
\hline 25 & body & fine bone & $\mathrm{B}$ & - & 6.5 & plain \\
\hline 35 & body & fine bone & B & E B & 4.7 & plain \\
\hline 37 & body & fine bone & G & - & 6.9 & plain \\
\hline 39 & rim & fine bone & $\mathrm{F}$ & E SM & 8.9 & $\begin{array}{l}\text { plain; inverted rim } \\
\text { and rounded lip; } \\
\text { interior thickened; } \\
\text { short rim }\end{array}$ \\
\hline 27 & body & $\begin{array}{l}\text { fine bone- } \\
\text { hematite }\end{array}$ & G & E SM & 5.5 & plain \\
\hline 28 & body & bone & $\mathrm{F}$ & I SM & 5.5 & parallel brushed \\
\hline 28 & body & bone & G & - & 5.6 & opposed brushed \\
\hline 37 & body & bone & $\mathrm{F}$ & - & 6.9 & parallel brushed \\
\hline 24 & body & $\begin{array}{l}\text { bone- } \\
\text { hematite }\end{array}$ & G & I SM & 6.9 & plain \\
\hline 24 & body & $\begin{array}{l}\text { bone- } \\
\text { hematite }\end{array}$ & B & - & 7.7 & parallel brushed \\
\hline 25 & body & $\begin{array}{l}\text { bone- } \\
\text { hematite }\end{array}$ & $\mathrm{F}$ & - & 7.8 & parallel brushed \\
\hline 29 & body & $\begin{array}{l}\text { bone- } \\
\text { hematite }\end{array}$ & B & - & N/A & plain \\
\hline 29 & rim & $\begin{array}{l}\text { bone- } \\
\text { hematite }\end{array}$ & $\mathrm{F}$ & - & 6.3 & $\begin{array}{l}\text { plain; direct rim } \\
\text { and rounded lip }\end{array}$ \\
\hline 29 & body & $\begin{array}{l}\text { bone- } \\
\text { hematite }\end{array}$ & $\mathrm{F}$ & - & 7.0 & parallel brushed \\
\hline
\end{tabular}




\begin{tabular}{|c|c|c|c|c|c|c|}
\hline Lot No. & $\begin{array}{l}\text { Sherd } \\
\text { Type }\end{array}$ & $\begin{array}{l}\text { Temper/ } \\
\text { Paste }\end{array}$ & $\mathrm{FC}$ & ST & $\begin{array}{l}\text { Th } \\
(\mathrm{mm})\end{array}$ & Comments \\
\hline 11 & body & grog & G & - & 7.3 & plain \\
\hline 24 & body & grog & $\mathrm{F}$ & I SM & 7.3 & plain \\
\hline 25 & body & grog & G & $\mathrm{I} / \mathrm{E} \mathrm{B}$ & 7.0 & plain \\
\hline 25 & body & grog & $\mathrm{F}$ & E B & 7.3 & plain; possible black slip \\
\hline 27 & body & grog & $\mathrm{K}$ & E B & 6.4 & plain \\
\hline 27 & body & grog & $\mathrm{G}$ & E SM & 6.6 & plain \\
\hline 28 & body & grog & $\mathrm{C}$ & $\mathrm{I} / \mathrm{E} \mathrm{B}$ & 6.8 & plain \\
\hline 25 & body & $\begin{array}{l}\text { grog- } \\
\text { hematite }\end{array}$ & A & - & 8.4 & plain \\
\hline 6 & body & shell & $\mathrm{B}$ & I SM & 6.3 & $\begin{array}{l}\text { two closely-spaced } \\
\text { curvilinear incised lines }\end{array}$ \\
\hline 20 & rim & shell & $\mathrm{B}$ & I SM & 7.0 & plain; rounded lip \\
\hline 24 & body & shell & B & $\begin{array}{l}\mathrm{I} / \mathrm{E} \\
\mathrm{SM}\end{array}$ & 7.3 & $\begin{array}{l}\text { parallel and opposed } \\
\text { incised lines }\end{array}$ \\
\hline 24 & $\begin{array}{l}\text { lower rim } \\
\text { and body }\end{array}$ & shell & $\mathrm{B}$ & - & 7.2 & plain \\
\hline 24 & body & shell & B & - & 6.9 & plain \\
\hline 24 & rim & shell & B & - & 7.6 & $\begin{array}{l}\text { plain; everted rim and } \\
\text { rounded lip }\end{array}$ \\
\hline 24 & body & shell & B & - & 7.7 & plain \\
\hline 24 & body & shell & B & - & 7.1 & plain \\
\hline 25 & body & shell & A & - & 7.4 & plain \\
\hline 25 & body & shell & B & - & 6.1 & plain \\
\hline 25 & base & shell & B & E SM & 8.3 & plain \\
\hline 25 & body & shell & B & - & 6.8 & $\begin{array}{l}\text { two closely-spaced } \\
\text { straight incised lines }\end{array}$ \\
\hline 27 & rim & shell & B & - & 6.9 & $\begin{array}{l}\text { horizontal grooved; } \\
\text { direct rim and } \\
\text { rounded lip }\end{array}$ \\
\hline 28 & body & shell & B & I SM & 6.1 & $\begin{array}{l}\text { opposed curvilinear } \\
\text { incised lines; Emory } \\
\text { Punctated Incised }\end{array}$ \\
\hline
\end{tabular}


20 Journal of Northeast Texas Archaeology 37 (2012)

\begin{tabular}{|c|c|c|c|c|c|c|}
\hline Lot No. & $\begin{array}{l}\text { Sherd } \\
\text { Type }\end{array}$ & $\begin{array}{l}\text { Temper/ } \\
\text { Paste }\end{array}$ & $\mathrm{FC}$ & ST & $\begin{array}{l}\text { Th } \\
(\mathrm{mm})\end{array}$ & Comments \\
\hline 28 & rim & shell & B & I SM & 8.3 & $\begin{array}{l}\text { two rows of punctations } \\
\text { below the lip; Emory } \\
\text { Punctated-Incised }\end{array}$ \\
\hline 29 & $\begin{array}{l}\text { lower rim } \\
\text { and body }\end{array}$ & shell & B & - & 8.4 & plain; collared rim \\
\hline 29 & body & shell & B & - & 7.1 & plain \\
\hline 29 & body & shell & B & - & 6.5 & plain \\
\hline 25 & body & fine SP & G & $\mathrm{I} / \mathrm{E} \mathrm{B}$ & 6.7 & $\begin{array}{l}\text { engraved pendant } \\
\text { triangles; cf. } \\
\text { Womack Engraved }\end{array}$ \\
\hline 30 & body & fine SP & $\mathrm{C}$ & $\begin{array}{l}\mathrm{I} / \mathrm{E} \\
\mathrm{SM}\end{array}$ & 5.9 & plain \\
\hline
\end{tabular}

\section{F-B4}

$\begin{array}{lllllll}4 & \text { body } & \text { fine bone } & \text { G } & \text { E SM } & 4.8 & \text { plain } \\ 4 & \text { body } & \text { fine bone } & \text { H } & - & 4.9 & \text { parallel brushed } \\ 5 & \text { body } & \text { fine bone } & \text { H } & \text { I SM } & 5.9 & \text { parallel brushed } \\ 9 & \text { body } & \text { fine bone } & \text { B } & \text { I SM } & 5.9 & \text { parallel brushed } \\ 11 & \text { body } & \text { fine bone } & \text { F } & - & 5.1 & \text { parallel brushed } \\ 12 & \text { body } & \text { fine bone } & \text { H } & \text { I SM } & 6.5 & \text { parallel brushed } \\ 17 & \text { base } & \text { fine bone } & \text { B } & - & 9.2 & \text { concave base, plain } \\ 23 & \text { body } & \text { fine bone } & \text { B } & - & 5.7 & \text { parallel brushed } \\ 25 & \text { body } & \text { fine bone } & \text { B } & \text { I/E } & 5.5 & \text { plain } \\ 26 & \text { body } & \text { fine bone } & \text { B } & - & 6.4 & \text { plain } \\ 26 & \text { lower rim } & \text { fine bone } & \text { B } & \text { I SM } & 6.9 & \text { tool punctated row } \\ 30 & \text { and body } & & & & & \\ 38 & \text { body } & \text { fine bone } & \text { B } & - & 5.7 & \text { parallel brushed } \\ 39 & \text { body } & \text { fine bone } & \text { H } & \text { I SM } & 5.4 & \text { parallel brushed } \\ 46 & \text { body } & \text { fine bone } & \text { H } & - & 6.5 & \text { parallel brushed } \\ \text { body } & \text { fine bone } & \text { H } & \text { I SM } & 5.6 & \text { parallel brushed } \\ & \text { body } & \text { fine bone } & \text { F } & - & 6.2 & \text { parallel brushed }\end{array}$




\begin{tabular}{|c|c|c|c|c|c|c|}
\hline Lot No. & $\begin{array}{l}\text { Sherd } \\
\text { Type }\end{array}$ & $\begin{array}{l}\text { Temper/ } \\
\text { Paste }\end{array}$ & $\mathrm{FC}$ & ST & $\begin{array}{l}\text { Th } \\
(\mathrm{mm})\end{array}$ & Comments \\
\hline 55 & body & fine bone & $\mathrm{H}$ & I SM & 6.0 & $\begin{array}{l}\text { horizontal and over- } \\
\text { lapping brushed }\end{array}$ \\
\hline 57 & body & fine bone & $\mathrm{H}$ & I SM & 7.2 & plain \\
\hline 65 & rim & fine bone & $\mathrm{B}$ & I SM & 5.5 & $\begin{array}{l}\text { plain; everted rim } \\
\text { and rounded, ext. } \\
\text { folded lip }\end{array}$ \\
\hline 67 & body & fine bone & G & I SM & 6.9 & parallel brushed \\
\hline 69 & body & fine bone & B & I SM & 6.6 & parallel brushed \\
\hline 72 & body & fine bone & $\mathrm{H}$ & I SM & 4.9 & parallel brushed \\
\hline 74 & body & fine bone & B & I SM & 6.2 & parallel brushed \\
\hline 30 & body & bone & B & - & 6.0 & plain \\
\hline 77 & body & $\begin{array}{l}\text { bone- } \\
\text { hematite }\end{array}$ & $\mathrm{A}$ & - & 6.4 & plain \\
\hline 54 & body & bone-shell & B & $\mathrm{I} / \mathrm{E} \mathrm{B}$ & 5.6 & opposed engraved lines \\
\hline 9 & rim & grog & B & $\mathrm{I} / \mathrm{E} \mathrm{B}$ & 6.5 & $\begin{array}{l}\text { cross-hatched } \\
\text { engraved; Womack } \\
\text { Engraved; direct rim } \\
\text { and rounded lip }\end{array}$ \\
\hline 13 & body & grog & B & I SM & 6.1 & parallel brushed \\
\hline 14 & body & grog & B & - & 5.5 & plain \\
\hline 16 & rim & grog & $\mathrm{F}$ & $\mathrm{I} / \mathrm{E} \mathrm{B}$ & 4.1 & $\begin{array}{l}\text { int./ext. red-slipped; } \\
\text { direct rim and } \\
\text { rounded lip }\end{array}$ \\
\hline 79 & body & grog & B & I SM & 5.2 & parallel brushed \\
\hline 63 & body & grog-bone & G & I SM & 6.7 & plain \\
\hline 47 & body & $\begin{array}{l}\text { hemat.-fine } \\
\text { SP }\end{array}$ & $\mathrm{F}$ & $\mathrm{I} / \mathrm{E} \mathrm{B}$ & 5.2 & $\begin{array}{l}\text { hatched engraved } \\
\text { triangle }\end{array}$ \\
\hline 57 & body & $\begin{array}{l}\text { hemat-fine } \\
\text { SP }\end{array}$ & $\mathrm{H}$ & $\begin{array}{l}\text { E B/ } \\
\text { I SM }\end{array}$ & 6.8 & opposed engraved lines \\
\hline 59 & body & $\begin{array}{l}\text { hemat.-fine } \\
\text { SP }\end{array}$ & $\mathrm{F}$ & E B & 5.3 & $\begin{array}{l}\text { curvilinear and } \\
\text { opposed engraved lines }\end{array}$ \\
\hline
\end{tabular}




\begin{tabular}{|c|c|c|c|c|c|c|}
\hline Lot No. & $\begin{array}{l}\text { Sherd } \\
\text { Type }\end{array}$ & $\begin{array}{l}\text { Temper/ } \\
\text { Paste }\end{array}$ & $\mathrm{FC}$ & ST & $\begin{array}{l}\text { Th } \\
(\mathrm{mm})\end{array}$ & Comments \\
\hline 70 & body & $\begin{array}{l}\text { hemat.-fine } \\
\text { SP }\end{array}$ & $\mathrm{F}$ & - & 5.6 & plain \\
\hline 73 & body & $\begin{array}{l}\text { hemat.-fine } \\
\text { SP }\end{array}$ & $\mathrm{F}$ & E B & 7.5 & $\begin{array}{l}\text { horizontal engraved } \\
\text { and cross-hatched } \\
\text { brackets }\end{array}$ \\
\hline 73 & body & $\begin{array}{l}\text { hemat.-fine } \\
\text { SP }\end{array}$ & $\mathrm{F}$ & E B & 6.6 & $\begin{array}{l}\text { parallel lines and } \\
\text { narrow hatched } \\
\text { zone; brown slip }\end{array}$ \\
\hline 2 & body & fine SP & B & $\begin{array}{l}\mathrm{I} / \mathrm{E} \\
\mathrm{SM}\end{array}$ & 7.7 & $\begin{array}{l}\text { cross-hatched } \\
\text { engraved zone, } \\
\text { Womack Engraved }\end{array}$ \\
\hline 4 & body & fine SP & $\mathrm{E}$ & I SM & 5.4 & parallel brushed \\
\hline 24 & body & fine SP & - & E B & - & plain \\
\hline 42 & body & fine SP & $\mathrm{H}$ & I/E B & 7.4 & $\begin{array}{l}\text { straight and curvi- } \\
\text { linear engraved lines }\end{array}$ \\
\hline 70 & body & fine SP & $\mathrm{F}$ & - & 6.0 & $\begin{array}{l}\text { cross-hatched } \\
\text { engraved zone }\end{array}$ \\
\hline 77 & body & fine SP & B & $\begin{array}{l}\mathrm{I} / \mathrm{E} \\
\mathrm{SM}\end{array}$ & 7.9 & plain \\
\hline 80 & body & fine SP & $\mathrm{H}$ & E B & 6.0 & $\begin{array}{l}\text { horizontal and } \\
\text { diagonal engraved } \\
\text { lines and hatched } \\
\text { triangles }\end{array}$ \\
\hline 80 & body & fine SP & $\mathrm{F}$ & E SM & 6.2 & $\begin{array}{l}\text { engraved scroll and } \\
\text { hatched triangle }\end{array}$ \\
\hline 16 & rim & shell & $\mathrm{F}$ & - & 6.9 & $\begin{array}{l}\text { plain; inverted rim } \\
\text { and rounded lip }\end{array}$ \\
\hline 20 & body & shell & $\mathrm{K}$ & - & 6.7 & straight incised line \\
\hline 20 & body & shell & $\mathrm{E}$ & - & 6.5 & plain \\
\hline 56 & body & shell & B & $\mathrm{I} / \mathrm{E} \mathrm{B}$ & 5.6 & plain \\
\hline 68 & body & shell & B & I B & 3.6 & plain \\
\hline
\end{tabular}

hemat.=hematite; SP=sandy paste; Firing conditions (after Teltser 1993:Figure 2a-h; Perttula 2005:Figure 5-30i-1): A=fired and cooled in an oxidizing environment; $\mathrm{B}=$ fired and cooled in a reducing environment; $\mathrm{C}$-E=incompletely oxidized;

$\mathrm{F}-\mathrm{H}=$ fired in a reducing environment and cooled in the open air; $\mathrm{K}-\mathrm{L}=$ =sooted, smudged, or refired; I=interior; E=exterior; $\mathrm{SM}=$ smoothed; $\mathrm{B}=$ burnished 